\title{
Effects of a novel carbohydrate fraction on broiler performance and intestinal function
}

\author{
M. Ivković ${ }^{1 \#}$, L. Perić ${ }^{1}$, D. Žikić ${ }^{1}$, D. Cvetković ${ }^{2}$ D. Glamočić ${ }^{1} \&$ P. Spring ${ }^{3}$ \\ ${ }^{1}$ Department of Animal Science, Faculty of Agriculture, Novi Sad University, Novi Sad, Serbia \\ ${ }^{2}$ Faculty of Technology, Novi Sad University, Novi Sad, Serbia \\ ${ }^{3}$ Swiss College of Agriculture, Zollikofen, Switzerland
}

\begin{abstract}
Copyright resides with the authors in terms of the Creative Commons Attribution 2.5 South African Licence.
See: http://creativecommons.org/licenses/by/2.5/za

Condition of use: The user may copy, distribute, transmit and adapt the work, but must recognise the authors and the South African Journal of Animal Science.
\end{abstract}

\begin{abstract}
This study was performed to determine the effects of a natural yeast-based feed ingredient (natural carbohydrate fraction (NCF) isolated from a specific strain of yeast) on broiler chickens, and to examine its mode of action. The trial was set up as a complete randomized design with three treatments and eight replicates (38 Ross 308 chickens per pen). Two levels of NCF, $0.2 \mathrm{~g} / \mathrm{kg}$ and $0.4 \mathrm{~g} / \mathrm{kg}$, were compared to a negative control. The NCF addition increased body weight during the initial period, but this benefit was lost towards the end of the trial. Feed conversion ratio was improved significantly with $0.4 \mathrm{~g} \mathrm{NCF} / \mathrm{kg}(1.79$ compared with 1.83 in control group). Mortality was numerically lower in the groups receiving NCF. Significant effects on caecal bacterial population were not found. Intestine length and weight were not affected by treatments, while some changes in intestine histology were found. The area described as the 'cup' of mucus-producing cells, representing the quantity of stored mucins, was significantly larger in chickens receiving NCF. Relative weights of the spleen and bursa of Fabricius did not change significantly compared with the control. The NCF can improve performance and affects mucus-producing cells. Full elucidation of the mechanisms of action requires further research.
\end{abstract}

Keywords: Yeast, mucus, mucin, goblet cell, Sacharomyces cerevisiae cell wall products

${ }^{\#}$ Corresponding author: mirkomivkovic@gmail.com

\section{Introduction}

Yeast (Saccharomyces cerevisiae) has been used as a dietary ingredient for an extended period. Apart from its nutrient content, yeast cells, especially yeast cell wall components, have specific properties that can improve animal health. Feed ingredients based on yeast cell wall have been used increasingly in animal diets, especially after the ban on the use of antibiotic growth promoters in the EU (Castanon, 2007). A great deal of published research documents their positive effects on animal performance (Hooge, 2004a; b; Miguel et al., 2004; Perić et al., 2005; Rosen, 2006; 2007a; b; Close \& Taylor-Pickard, 2010; Žikić et al., 2011).

The yeast cell wall is a complex structure containing mannoprotein, two $\beta$-glucans and chitin (Cabib et al., 1991). What gives the yeast cell wall its beneficial properties is still not fully understood. Both mannans and $\beta$-glucans are known to be active compounds, and different modes of action are attributed to them. Yeast mannan and mannose (the structural component) block the bacterial lectins found on many Escherichia coli and Salmonella strains, and thus can prevent their adherence to the gut wall and further colonization (Spring et al., 2000). Changes in the populations of undesirable bacteria can affect other bacterial populations, gut morphology, effectiveness of digestion and feed utilization. It has been proven that mannan also binds with aflatoxin $\mathrm{B}_{1}$ and prevents its mutagenic and carcinogenic effect on liver cells when fed to mice (Madrigal-Santillan et al., 2009). Krizková et al. (2001) showed that mannans from different yeasts, including $S$. cerevisiae, have antioxidative and antimutagenic properties in vitro. This suggests that dietary mannan can protect the gastro-intestinal tract in ways other than just removing undesirable bacteria. 
Muchmore et al. (1990) investigated the immuno-modulatory effects of some high-mannose oligosaccharides. All of them inhibited T-cell proliferation in vitro, and mannan from yeast cell wall was the most active of them all. It was concluded from this research that carbohydrate structures may play a role in regulating human immune response (Muchmore et al., 1990). If so, dietary mannan may have a direct immuno-modulatory effect on animals consuming diets that contain such components. Two of the $\beta$-glucans found in the yeast cell wall contain two kinds of linkages: $\beta-(1,3)$ and $\beta-(1,6)$ (Cabib et al., 1991). One of these, the $\beta$-(1,3) bond, imparts immuno-modulatory properties to certain mushrooms (Kozarski et al., 2009). Yeast cell wall $\beta$-glucans may have antioxidant, antimutagenic and antigenotoxic activities (Kogan et al., 2008).

Bio-Mos ${ }^{\circledR}$ (Alltech Inc.) is a feed ingredient based on yeast cell wall. Its activity is commonly attributed to mannan-oligosaccharides, but this form of MOS is not pure mannan-oligosaccharide. It contains yeast cell wall fragments (Spring et al., 2000), and can be considered a glucomannoprotein complex (Newman, 1994). Many trials in poultry have demonstrated the effectiveness of Bio-Mos® in improving growth performance and reducing mortality (Rosen, 2007a). Analysis of peer-reviewed literature has shown a consistent improvement in piglet, sow, broiler and turkey performance (Hooge, 2004a; b; Miguel et al., 2004; Close \& Taylor-Pickard, 2010) when the additive has been included as a pronutrient in feed over a extended period.

More recently, a new yeast-based feed ingredient has become available: natural carbohydrate fraction (NCF), isolated from a specific strain of yeast (Actigen, Alltech Inc.). Brümmer et al. (2010) explored the effects of NCF on broiler chickens. They found a comparable effect to that observed with commercial doses of MOS when using 20 times lower concentrations of NCF ( 0.1 and $0.2 \mathrm{~g} \mathrm{NCF} / \mathrm{kg}$ vs. 2 and $4 \mathrm{~g} \mathrm{MOS} / \mathrm{kg}$ ). However, the researchers could not determine statistically significant benefits of NCF on productive performance, although this was only a small-scale study ( 35 birds per treatment) and this low number may not have allowed sufficient sensitivity to the treatment within the experimental design. Additionally, the positive effects on villus-crypt parameters that are usually associated with MOS (Baurhoo et al., 2007; Žikić et al., 2008; Perić et al., 2009) were not observed with NCF-treated birds. Major effects on mucus-producing cells were found, with both their size and their number being greater. Within the scope of this small-scale study, the effect of NCF on bacterial populations and immunity were not explored.

The aim of the following study was to test the effect of NCF on broiler performance in a larger-scale trial and to examine its effect on microbiological population of gut, gut health, mucin-producing cells and the immune system of broilers.

\section{Materials and Methods}

The trial was set up as a completely randomized design, with three treatments and eight pen replicates per treatment. Nine hundred and twelve one day-old Ross $308 \circledR$ mixed-sex broiler chickens were obtained from a local hatchery and randomly assigned to the experimental groups, giving 38 birds per replicate. Stocking density was 15 birds $/ \mathrm{m}^{2}$. Wheat straw was used as litter. Air temperature was adjusted in accordance with the recommendation of the genetic company. Birds were vaccinated against Newcastle disease (NCD) and infectious bursal disease (IBD) as per commercial recommendations. Feed and water were supplied ad libitum. Birds were fed a mash feed, and three diet phases were used: starter from $\mathrm{d} 1$ to $\mathrm{d}$ 14 , grower from d 15 to $\mathrm{d} 35$, and finisher from d 36 to $\mathrm{d} 42$. The composition of the basal diets is shown in Table 1.

The treatments were as follows: control-basal diets with no supplementary NCF, basal diet plus $0.2 \mathrm{~g}$ $\mathrm{NCF} / \mathrm{kg}$ and basal diet plus $0.4 \mathrm{~g} \mathrm{NCF} / \mathrm{kg}$. Actigen (Alltech Inc.) was used as the source of NCF. The body weight of the birds was measured weekly. Feed intake was recorded for each dietary period (starter, grower and finisher) for each pen. Based on the recorded data, feed conversion ratio (FCR) was calculated for each dietary period ( $1-14 \mathrm{~d}, 15-35 \mathrm{~d}, 36-42 \mathrm{~d})$. Mortality and culls were recorded daily. The FCR was corrected for the body weights of birds that died.

At 28 days old, 10 birds of average body weight were sacrificed from each treatment, and the following were measured: live body weight, duodenum, jejunum and ileum length, small intestine, liver, pancreas, spleen and bursa of Fabricius weights. Lengths of identified sections of the small intestine and total small intestine length were expressed as $\mathrm{cm} / 100 \mathrm{~g}$ of live body weight, and organ weights were expressed as percentage of live body weight. Small intestine weight per length was calculated. 
Tissue samples from the mid-section of the jejunum excised from the birds were washed with saline solution, placed in 10\% formaldehide and, after histological procedure, stained with Alcian Blue and Periodic Acid-Schiff reagent. Jejunal histology parameters were determined using light microscope and software for image analysis (IM1000 Image Manager, Leica). A minimum of 15 measurements per bird were made for evaluation of villus height and width, crypt depth and thickness of tunica muscularis externa. Villus width was measured at three points: close to the bottom, at the midpoint and close to the tip of the villus, and the average of these three measurements was used in the statistical analysis. Villus area was calculated by multiplying villus height with average villus width. The number of goblet cells was measured per length of villus edge, with only those cells touching villus edge being counted. Goblet cells were counted on 15 sections, with an average section length of $310 \mu \mathrm{m}$. Size of goblet cell cup was measured on at least 90 individual goblet cells (125 on average). Only clearly visible good cross-sections of goblet cells touching the villus edge were used in this analysis.

Table 1 Ingredient and nutrient composition of basal diets

\begin{tabular}{|c|c|c|c|}
\hline & Starter $(1-14 d)$ & Grower (15-35 d) & Finisher $(36-42 \mathrm{~d})$ \\
\hline \multicolumn{4}{|l|}{ Diet composition $(\mathrm{g} / \mathrm{kg})$} \\
\hline Maize & 447 & 524 & 582 \\
\hline Full fat soya & 200 & 170 & 140 \\
\hline Soybean meal & 264 & 220 & 190 \\
\hline Oil & 40 & 40 & 42 \\
\hline Monocalcium phosphate & 15 & 15 & 15 \\
\hline Limestone & 18 & 15 & 15 \\
\hline Salt & 3 & 3 & 3 \\
\hline DL-methionine & 2 & 2 & 2 \\
\hline L-lysine & 1 & 1 & 1 \\
\hline Vitamin and mineral premix & 10 & 10 & 10 \\
\hline Actigen* & 0 & 0 & 0 \\
\hline \multicolumn{4}{|l|}{ Calculated nutrient composition } \\
\hline $\operatorname{AME}(\mathrm{MJ} / \mathrm{kg})$ & 12.96 & 13.21 & 13.39 \\
\hline Crude protein (g/kg) & 226.7 & 202.6 & 183.1 \\
\hline Lysine $(\mathrm{g} / \mathrm{kg})$ & 14.2 & 12.4 & 10.9 \\
\hline Methionine $(\mathrm{g} / \mathrm{kg})$ & 5.5 & 5.2 & 4.9 \\
\hline Calcium $(\mathrm{g} / \mathrm{kg})$ & 10.7 & 9.4 & 9.2 \\
\hline Phosphorus (g/kg) & 7.3 & 7.0 & 6.8 \\
\hline
\end{tabular}

*Actigen natural carbohydrate fraction (NCF) was added at 0.2 and $0.4 \mathrm{~g} / \mathrm{kg}$, respectively, in the experimental treatments.

AME - Apparent metabolisable energy.

Samples of caecal ingesta were taken from sacrificed birds. They were homogenated in buffered peptone water, and decimal dilutions were prepared. Conventional microbiological techniques with selective agars were used for analysis. The following agars were used for determining bacterial groups: for total aerobes, nutrient agar (Merck); for total anaerobes, Wilkens-Chalgren agar (HiMedia); for lactic acid bacteria, MRS agar (HiMedia); for Bifidobacterium spp., Wilkens-Chalgren agar with recommended supplements (HiMedia); for E. coli, Chromocult Coliform agar (Merck); and for Enterococci, Chromocult Enterococci agar (Merck). Anaerobic conditions required for the cultivation of obligatory and facultative anaerobes were achieved in an anaerobic jar using Anaerocult ${ }^{\circledR}$ A (Merck). Anaerobic conditions were 
checked with Anaerotest ${ }^{\circledR}$ A (Merck). Results were expressed as $\log _{10}$ of the number of colony forming units per gram of caecal digesta $(\log \mathrm{cfu} / \mathrm{g})$.

Performance results were analysed using simple linear regression. Intestine and organ measurements, jejunal histology and microbiological analysis of caecal ingesta were analysed by one-way ANOVA using general linear models, and with means separated by the Duncan Multiple Range Test, using Statistica (StatSoft, Inc., version 8.0, 2008). Results were considered significant when $P<0.05$.

All procedures were conducted according to ethical norms proposed by the European Convention for the Protection of Vertebrate Animals Used for Experimental and Other Scientific Purposes, confirmed by Serbian authorities (Službeni glasnik RS-Međunarodni ugovori, 1/2010).

\section{Results}

The performance results are shown in Table 2. Regression coefficients for body weights at all ages were not significantly different from zero $(P>0.05)$. Regression coefficients for FCR of grower feed and FCR for whole trial period were negative and significantly different from zero $(P<0.05)$, indicating that NCF addition improves FCR. Regression coefficient for mortality were high, negative, but, owing to high standard error, not significantly different from zero $(P>0.05)$.

Table 2 Body weight, feed conversion ratio and mortality rate of broiler chickens as affected by NCF* supplementation-means and linear regression analysis results

\begin{tabular}{|c|c|c|c|c|c|c|c|c|c|}
\hline & \multirow{2}{*}{\multicolumn{3}{|c|}{$\begin{array}{c}\text { NCF inclusion rate } \\
\qquad(\mathrm{g} / \mathrm{kg})\end{array}$}} & \multirow{3}{*}{$\begin{array}{l}\text { Residual } \\
\text { M.S. }\end{array}$} & \multicolumn{5}{|c|}{ Linear regression parameters } \\
\hline & & & & & \multicolumn{2}{|c|}{ Constant } & \multicolumn{3}{|c|}{ NCF inclusion } \\
\hline & 0 & 0.2 & 0.4 & & Estimate & SE & Estimate & SE & $P$ value \\
\hline \multicolumn{10}{|l|}{ Body weight (g) } \\
\hline Day 1 & 41.3 & 41.2 & 41.2 & 0.028 & 41.2 & 0.08 & -0.14 & 0.30 & 0.649 \\
\hline Day 7 & 166 & 167 & 163 & 32.14 & 167 & 2.63 & -7.80 & 10.02 & 0.456 \\
\hline Day 14 & 358 & 373 & 362 & 153.5 & 362 & 5.64 & 9.41 & 21.83 & 0.676 \\
\hline Day 21 & 737 & 757 & 740 & 474.8 & 744 & 7.03 & 7.37 & 27.24 & 0.789 \\
\hline Day 28 & 1272 & 1271 & 1276 & 1088 & 1271 & 11.25 & 10.74 & 42.64 & 0.804 \\
\hline Day 35 & 1840 & 1847 & 1859 & 1699 & 1840 & 13.30 & 47.08 & 51.52 & 0.371 \\
\hline Day 42 & 2397 & 2383 & 2392 & 2962 & 2393 & 17.57 & -12.02 & 68.04 & 0.861 \\
\hline \multicolumn{10}{|c|}{ Feed conversion ratio } \\
\hline $0-14 \mathrm{~d}$ & 1.59 & 1.53 & 1.55 & 0.003 & 1.58 & 0.017 & -0.11 & 0.06 & 0.109 \\
\hline $15-35 \mathrm{~d}$ & 1.70 & 1.71 & 1.65 & 0.001 & 1.71 & 0.010 & -0.12 & 0.04 & 0.005 \\
\hline $36-42 \mathrm{~d}$ & 2.37 & 2.44 & 2.38 & 0.031 & 2.39 & 0.057 & 0.03 & 0.22 & 0.880 \\
\hline $0-42 \mathrm{~d}$ & 1.83 & 1.83 & 1.79 & 0.001 & 1.84 & 0.011 & -0.10 & 0.04 & 0.031 \\
\hline \multicolumn{10}{|l|}{ Mortality rate $(\%)$} \\
\hline $0-42 \mathrm{~d}$ & 4.39 & 3.72 & 2.70 & 10.55 & 4.45 & 1.048 & -4.22 & 4.06 & 0.310 \\
\hline
\end{tabular}

* NCF - novel carbohydrate fraction.

The addition of NCF did not induce significant changes in microbial populations in the caecal ingesta (Table 3). Numerically, the numbers of Bifidobacteria spp. and Enterococi spp. were larger in NCF-fed groups, while numbers of $E$. coli and total aerobes were lower in these groups.

The overall lengths of the small intestine and its sections were similar $(P>0.05)$ in all groups (Table 4). Birds from the NCF $(0.4 \mathrm{~g} / \mathrm{kg})$ group had a numerically lighter small intestine. Groups receiving NCF had heavier spleens and bursas. No significant differences were observed for these parameters.

Histological parameters of the jejunum are shown in Table 5. The expected improvements in villus height and reduction of crypt depth were not observed. On the contrary, villus height was smallest and crypt 
depth largest in the NCF $(0.2 \mathrm{~g} / \mathrm{kg})$ group. These numeric changes led to a significant $(P<0.05)$ reduction of villus to crypt ratio. The NCF $(0.2 \mathrm{~g} / \mathrm{kg})$ group had a smaller villus area compared with the group receiving $0.4 \mathrm{~g} \mathrm{NCF} / \mathrm{kg}$. The strongest effect noted for NCF-fed birds was the enlargement of the goblet cell cup size. It was significantly larger in both groups receiving NCF. The number of goblet cells was higher in these groups, but this effect was not significant.

Table 3 Microbial population of caecum ingesta of 28 days old broiler chickens as affected by NCF* supplementation, expressed as log cfu/g (mean $\pm \mathrm{SE}$ )

\begin{tabular}{lccccc}
\hline & Control & NCF $(0.2 \mathrm{~g} / \mathrm{kg})$ & NCF $(0.4 \mathrm{~g} / \mathrm{kg})$ & SEM & $P$ value \\
\hline Total aerobes & $8.91 \pm 0.12$ & $8.71 \pm 0.10$ & $8.81 \pm 0.11$ & 0.063 & 0.437 \\
Total anaerobs & $9.68 \pm 0.08$ & $9.68 \pm 0.08$ & $9.74 \pm 0.10$ & 0.049 & 0.855 \\
Lactic acid bacteria & $8.48 \pm 0.09$ & $8.41 \pm 0.07$ & $8.62 \pm 0.12$ & 0.055 & 0.284 \\
Bifidobacteria & $7.03 \pm 0.21$ & $7.25 \pm 0.29$ & $7.23 \pm 0.27$ & 0.145 & 0.790 \\
Enterococi & $7.53 \pm 0.20$ & $7.74 \pm 0.19$ & $7.96 \pm 0.20$ & 0.116 & 0.316 \\
E. coli & $7.21 \pm 0.15$ & $7.17 \pm 0.19$ & $7.03 \pm 0.18$ & 0.099 & 0.752 \\
\hline
\end{tabular}

$* \mathrm{NCF}$ - novel carbohydrate fraction.

SEM - standard error of mean.

Table 4 Intestine length, intestine and organ weight of 28 days old broiler chickens as affected by NCF* supplementation (mean $\pm \mathrm{SE}$ )

\begin{tabular}{lccccc}
\hline & Control & NCF $(0.2 \mathrm{~g} / \mathrm{kg})$ & $\mathrm{NCF}(0.4 \mathrm{~g} / \mathrm{kg})$ & SEM & $P$ value \\
\hline Intestine length (cm/100 g BW) & & & & & \\
$\quad$ Duodenum & $2.49 \pm 0.06$ & $2.43 \pm 0.07$ & $2.49 \pm 0.09$ & 0.044 & 0.769 \\
$\quad$ Jejunum & $5.88 \pm 0.28$ & $6.06 \pm 0.29$ & $6.04 \pm 0.24$ & 0.151 & 0.738 \\
$\quad$ Ileum & $5.97 \pm 0.28$ & $6.04 \pm 0.27$ & $5.90 \pm 0.30$ & 0.159 & 0.868 \\
$\quad$ Small intestine & $14.34 \pm 0.57$ & $14.53 \pm 0.58$ & $14.42 \pm 0.59$ & 0.325 & 0.937 \\
Intestine weight & & & & & \\
$\quad$ \% BW & $8.33 \pm 0.22$ & $8.37 \pm 0.41$ & $7.87 \pm 0.43$ & 0.209 & 0.433 \\
$\quad$ g/cm intestine & $0.59 \pm 0.03$ & $0.58 \pm 0.04$ & $0.56 \pm 0.05$ & 0.022 & 0.529 \\
Organ weight (\% BW) & & & & & \\
$\quad$ Liver & $2.61 \pm 0.11$ & $2.56 \pm 0.12$ & $2.51 \pm 0.11$ & 0.063 & 0.733 \\
$\quad$ Pancreas & $0.35 \pm 0.01$ & $0.33 \pm 0.01$ & $0.33 \pm 0.01$ & 0.008 & 0.332 \\
$\quad$ Spleen & $0.12 \pm 0.01$ & $0.14 \pm 0.01$ & $0.15 \pm 0.02$ & 0.008 & 0.306 \\
$\quad$ Bursa & $0.24 \pm 0.02$ & $0.29 \pm 0.03$ & $0.26 \pm 0.02$ & 0.012 & 0.252 \\
\end{tabular}

* NCF - novel carbohydrate fraction.

SEM - standard error of mean.

\section{Discussion}

The body weight of chickens in one NCF group was numerically larger than of the control chickens on d 14 and d 21, but this effect was not observed in later periods. This implies that NCF may have a more pronounced effect on young animals. In comparison with standardised performance targets (Aviagen, 2007), chick performance was poor in the early phase of the trial. They reached only $80 \%$ of the target weight set for d 14, whereas at d 35 and d 42 they attained more than $90 \%$ of weight objectives. This may indicate that 
the birds were exposed to more stress early in the trial. This suggests that the effect of the NCF is greater in animals that are suffering from physiological or other stresses compared with animals that are in good condition.

Improvement in FCR was achieved mainly during the early period of growth, but remained significant over the entire trial period. In the trial reported by Brümmer et al. (2010), FCR was improved in NCF-fed chickens, but the noted differences were not significant, possibly owing to the smaller number of birds in the trial. Also, in that trial, lower dosages of NCF were used $(0.1$ and $0.2 \mathrm{~g} / \mathrm{kg})$. The effect of NCF on survival rate of chickens could be important, but for determining a significant effect, larger trials with a more birds are needed.

Table 5 Jejunal morphometric parameters of 28 days old broiler chickens as affected by NCF* supplementation (mean $\pm \mathrm{SE}$ )

\begin{tabular}{lrrrrr}
\hline & \multicolumn{1}{c}{ Control } & NCF $(0.2 \mathrm{~g} / \mathrm{kg})$ & $\mathrm{NCF}(0.4 \mathrm{~g} / \mathrm{kg})$ & $\mathrm{SEM}$ & $P$ value \\
\hline Villus height $(\mu \mathrm{m})$ & $1129 \pm 73$ & $990 \pm 60$ & $1093 \pm 60$ & 37.8 & 0.255 \\
Crypt depth $(\mu \mathrm{m})$ & $384 \pm 39$ & $466 \pm 37$ & $383 \pm 18$ & 19.8 & 0.090 \\
Villus width $(\mu \mathrm{m})$ & $149 \pm 9$ & $150 \pm 10$ & $173 \pm 7$ & 5.37 & 0.085 \\
T. muscularis thickness $(\mu \mathrm{m})$ & $248 \pm 22$ & $247 \pm 22$ & $217 \pm 15$ & 11.4 & 0.450 \\
Villus area $\left(\mathrm{mm}^{2}\right)$ & $0.17^{\mathrm{ab}} \pm 0.01$ & $0.15^{\mathrm{b}} \pm 0.01$ & $0.19^{\mathrm{a}} \pm 0.01$ & 0.01 & 0.107 \\
Villus/crypth ratio & $3.2^{\mathrm{a}} \pm 0.29$ & $2.3^{\mathrm{b}} \pm 0.18$ & $3.0^{\mathrm{a}} \pm 0.28$ & 0.16 & 0.026 \\
Villus height/width & $8.3 \pm 0.84$ & $7.2 \pm 0.66$ & $6.7 \pm 0.48$ & 0.40 & 0.116 \\
Goblet cell density $(1 / 100 \mu \mathrm{m})$ & $7.9 \pm 0.43$ & $9.1 \pm 0.42$ & $8.6 \pm 0.33$ & 0.24 & 0.143 \\
Goblet cell cup size $\left(\mu \mathrm{m}^{2}\right)$ & $39^{\mathrm{b}} \pm 3$ & $61^{\mathrm{a}} \pm 6$ & $52^{\mathrm{a}} \pm 5$ & 3.01 & 0.007 \\
& & & & & \\
\hline
\end{tabular}

* NCF - novel carbohydrate fraction.

${ }^{\text {a.b }}$ Row means with different superscripts differ significantly at $P<0.05$.

SEM - standard error of mean.

An enlargement of goblet cell cup size was clearly observed in this trial, as in the previous reported work with NCF (Brümmer et al., 2010) and has also been observed in trials with MOS (Baurhoo et al., 2009). Greater cup size means that there was more mucin in the cell, which can be the result of greater mucin synthesis or slower mucin secretion. This was linked with changes in populations of Lactobacillus and Bifidobacterium spp. (Smirnov et al., 2005), or just Bifidobacterium spp. (Baurhoo et al., 2009), but in this trial the population of these bacterial groups was not significantly affected by treatment. These findings could be the result of using a more sensitive method for goblet cell size analysis and a less sensitive method for microbial population analysis.

According to Morales-López et al. (2009), yeast cell wall supplements may act as non-pathogenic microbial antigens, stimulating growth of lymphoid tissue. Relative weights of lymphoid organs of spleen and bursa of Fabricius were not altered significantly with NCF addition. Therefore, this potential mechanism of action could not be confirmed with the data from this trial. Changes in villus height and crypt depth were inconsistent, with some changes moving in the opposite direction from expected, depending on the NCF inclusion level. More research is needed to understand the effects of NCF on intestinal morphology.

\section{Conclusion}

The new yeast-based feed ingredient, NCF, can improve broiler chicken performance at low inclusion levels $(0.4 \mathrm{~g} / \mathrm{kg})$, and has a greater impact on FCR than on body weight. It is confirmed that NCF affects mucus-producing cells positively, although it is not clear whether increased goblet cell cup size is connected with improved performance, and the mechanisms of action of NCF need to be explored further. 


\section{References}

Aviagen, 2007. Ross 308 broiler: Performance objectives. http://en.aviagen.com/ross-308/

Baurhoo, B., Phillip, L. \& Ruiz-Feria, C.A., 2007. Effects of purified lignin and mannan oligosaccharides on intestinal integrity and microbial population in ceca and litter of broiler chickens. Poult. Sci. 86, 1070-1078.

Baurhoo, B., Ferket, P.R. \& Zhao, X., 2009. Effects of diets containing different concentrations of mannanoligosaccharide or antibiotics on growth performance, intestinal development, cecal and litter microbial population and carcass parameters of broilers. Poult. Sci. 88, 2262-2272.

Brümmer, M., Jansen van Rensburg, C. \& Moran, C.A., 2010. Sacharomyces cerevisiae cell wall products: The effect on gut morphology and performance of broiler chickens. S. Afr. J. Anim. Sci. 40, 14-21.

Cabib, E., Silverman, S.J., Shaw, J.A., Das Gupta, S., Park, H.M., Mullins, J.T., Mol, P.C. \& Bowers, B., 1991. Carbohydrates as structural constituents of yeast cell wall and septum. Pure \& Appl. Chem. 63, (4), 483-489.

Castanon, J.I.R., 2007. History of use of antibiotics as growth promoters in European poultry feeds. Poult. Sci. 86, 2466-2471.

Close, W.H. \& Taylor-Pickard, J., 2010. Feeding sows MOS aids. Feedstuffs, August 1, 2010.

Hooge, D.M., 2004a. Meta-analysis of broiler chicken pen trials evaluating dietary mannan oligosaccharide, 1993-2003. Int. J. Poult. Sci. 3, 163-174.

Hooge, D.M., 2004b. Turkey pen trials with dietary mannan oligosaccharide: meta-analysis, 1993-2003. Int. J. Poult. Sci. 3, 179-188.

Kogan, G., Pajtinka, M., Babincova, M., Miadokova, E., Rauko, P., Slamenova, D. \& Korolenko, T.A., 2008. Yeast cell wall polysaccharides as antioxidants and antimutagens: can they fight cancer? Neoplasma 55 (5), 387-393.

Kozarski, M.S., Klaus, A.S. \& Nikšić, M.P., 2009. Influence of structural features on immuno-stimulating activity of glucans extracted from Agaricus Blazei mushroom. Zb. Matice Srp. Prir. Nauke 116, 225-233.

Krizková, L., Duracková, Z., Sandula, J., Sasinková, V. \& Krajcovic, J., 2001. Antioxidative and antimutagenic activity of yeast cell wall mannans in vitro. Mutat. Res. 497, 213-222.

Madrigal-Santillán, E., Morales-González, J.A., Sánchez-Gutiérrez, M., Reyes-Arellano, A. \& MadrigalBujaidar, E., 2009. Investigation on the protective effect of $\alpha$-mannan against the DNA damage induced by aflatoxin B1 in mouse hepatocytes. Int. J. Mol. Sci. 10, 395-406.

Miguel, J.C., Rodriguez-Zas, S.L. \& Pettigrew, J.E., 2004. Efficacy of a mannan oligosaccharide (BioMos®) for improving nursery pig performance. J. Swine Health Prod. 12 (6), 296-307.

Morales-López, R., Auclair, E., Garcia, F., Esteve-Garcia, E. \& Brufau, J., 2009. Use of yeast cell walls: 及-1,3/1,6-glucans; and mannoproteins in broiler chicken diets. Poult. Sci. 88, 601-607.

Muchmore, A.V., Sathyamoorthy, N., Decker, J. \& Sherblom, A.P., 1900. Evidence that specific highmannose oligosaccharides can directly inhibit antigen-driven T-cell responses. J. Leukocyte Biol. 48, 457-464.

Newman, K., 1994. Mannan-oligosaccharides: Natural polymers with significant impact on the gastrointestinal microflora and immune system. In: Biotechnology in the Feed Industry: Proc. Alltech 10th Annual Symposium. Eds Lyons, T.P. \& Jaques, K.A., Nottingham University Press, Nottingham, UK. pp. 167-174.

Perić, L., Ušćebrka, G., Žikić, D., Vranješ, M. \& Nollet, L., 2005. Effects of Bio-Mos supplementation on the performance of broiler chicks: a Serbian study. 15th European Symposium on Poultry Nutrition, Book of Proceedings, 304-306, Balatonfured, Hungary.

Perić, L., Žikić, D. \& Lukić, M., 2009. Application of alternative growth promoters in broiler production. Biotechnology in Animal Husbandry 25 (5-6), 387-398

Rosen, G.D., 2006. Holo-analysis of the efficacy of Bio-Mos in pig nutrition. Anim. Sci. 82, 683-689.

Rosen, G.D., 2007a. Holo-analysis of the efficacy of Bio-Mos in broiler nutrition. Br. Poult Sci. 48(1), 21-26.

Rosen, G.D., 2007b. Holo-analysis of the efficacy of Bio-Mos in turkey nutrition. Br. Poult Sci. 48(1), 27-32.

Službeni glasnik RS-Međunarodni ugovori, 1/2010. Law on Ratification of the European convention for the protection of vertebrate animals used for experimental and other scientific purposes (In Serbian). 
Smirnov, A., Perez, R., Amit-Romach, E., Sklan, D. \& Uni, Z., 2005. Mucin dynamics and microbial populations in the chicken small intestine are changed by dietary probiotic and antibiotic growth promoter supplements. J. Nutr. 135, 187-192.

Spring, P., Wenk, C., Dawson, K.A. \& Newman, K.E., 2000. The effects of dietary mannanoligosaccharides on cecal parameters and the concentrations of enteric bacteria in the ceca of salmonella-challenged broiler chicks. Poult. Sci. 79, 205-211.

Žikić, D., Perić, L., Ušćebrka, G., Stojanović, S., Milić, D. \& Nollet, L., 2008. Effect of prebiotics in broiler breeder and broiler diets on performance and jejunum morphology of broiler chickens. 1st Mediterranean Summit of WPSA, Book of Proceedings, 879-882, Porto Carras, Greece.

Žikić, D., Perić, L., Ušćebrka, G., Stojanović, S., Milić, D. \& Nollet, L., 2011. Influence of dietary mannanoligosaccharides on histological parameters of the jejunal mucosa and growth performance of broiler chickens. Afr. J. Biotechnol. 10 (32), 6172-6176. 